\title{
METODE PEMBELAJARAN BAHASA SASTRA PROSEDUR DAN KULTUR
}

\author{
Meyridah \\ SMAN Tambang Ulang, Tanah Laut \\ merydah76@gmail.com
}

\begin{abstract}
Abstrak
Tulisan ini bertujuan memberikan kontribusi pemikiran terhadap implementasi pembelajaran bahsa-sastra di sekolah yang selama ini masih memunculkan berbagai kendala khususnya yang bergayutan dengan pemikiran metode. Terkait dengan pemikiran atau penerapan metode ada dua aspek yang sangat esensial untuk diperhatikan, yaitu prosedur dan kultur. Prosedur dapat dimaknai bahwa dalam penerapan metode idealnya mempertimbangkan perkembangan intelektual pembelajar, fasilitas di sekolah, dan penyesuaian sifat dan tujuan pembelajar. Sementara yang berkenaan dengan kultur mengisyaratkan agar pengajar senantiasa memanfaatkan latar belakang sosial budaya dalam mengimplementasikan strategi pembelajaran bahasa-sastra.
\end{abstract}

Kata Kunci : metode pembelajaran, prosedur, dan kultur.

\section{PENDAHULUAN}

Sebagaimana diketahui bahwa bahasa memiliki peran yang sangat esensial dalam berkomunikasi. Peran bahasa yang esensial itu adalah sarana komunikasi. Oleh sebab itu, bahasa harus dipelajari setiap individu agar mudah dalam berkomunikasi. Dalam kaitannya dengan belajar bahasa dikenal dua terminologi yang diketengahkan para pakar, yaitu pemerolehan bahasa (language acquisition) dan pembelajaran bahasa (language learning). Pemerolehan bahasa berkenaan dengan bahasa pertama (B1), sedangkan pembelajaran bahasa berkaitan dengan bahasa kedua (B2). Konsepsi ini agak berbeda dengan pandangan Krashan (1988) yang menyebutkan bahwa, baik pemerolehan maupun pembelajaran dapat terjadi pada B2.

Secara khusus dalam makalah ini pembahasan akan difokuskan pada pembelajaran bahasa. Berbicara tentang pembelajaran bahasa, tentu tidak dapat dipisahkan dengan pembelajaran sastra. Sebab, kedua bidang itu (bahasa dan sastra) memiliki keterkaitan satu sama lain. Pembelajaran bahasa sastra dimaksudkan agar para pembelajar dapat menghayati bahasa dan sastra. Di 
samping itu, pembelajaran bahasa sastra diharapkan bisa membantu siswa untuk mengenal dirinya sendiri, budayanya, budaya orang lain, dan dapat menyampaikan gagasan.

Dalam konteks pembelajaran bahasa-sastra ada beberapa komponen yang perlu diperhatikan. Salah satu komponen yang dimaksud adalah metode pembelajaran. Richards dan Rodgers (2007) menyatakan bahwa metode merupakan keseluruhan rencana untuk menyajikan atau mempresentasikan materi bahasa (bandingkan Brown dalam Richards dan Renandya, 2002 : 9). Atau, dapat juga dikatakan bahwa metode pembelajaran merupakan cara yang disusun dalam bentuk kegiatan nyata untuk mewujudkan tujuan pembelajaran.

Terkait dengan metode pembelajaran bahasa akan dikupas dua permasalahan pokok yang berkenaan dengan metode itu, yaitu prosedur dan kultur. Prosedur bertalian dengan pelaksanaan dan pemilihan metode dalam proses pembelajaran, sedangkan kultur berhubungan dengan aspek budaya yang perlu menjadi pertimbangan dalam menggunakan metode pembelajaran. Baik prosedur maupun kultur secara mendetail akan dipaparkan pembahasannya berikut ini.

\section{METODE}

\subsection{Prosedur}

Sebelumnya telah diketengahkan bahwa metode pembelajaran merupakan cara-cara yang ditempuh untuk menciptakan situasi pembelajaran yang kondusif, menyenangkan dan mendukung kelancaran pelaksanaan pembelajaran. Oleh sebab itu, dalam memilih metode pembelajaran seyogianya memperhatikan berbagai prosedur sebagai acuan. Sejalan dengan itu, Sunaryo (1995) (dalam sitirohmania.blogspot.com) menyebutkan kriteria pemilihan metode pembelajaran berikut : 1) menyesuaikan tingkat perkembangan intelektual dan sosial; 2) mempertimbangkan fasilitas yang tersedia di sekolah; dan 3) menyesuaikan sifat dan tujuan pembelajaran.

Kriteria pemilihan metode di atas tentu saja sangat penting untuk dijadikan pertimbangan. Sebab, jika metode yang digunakan tidak tepat, maka tujuan pembelajaran tidak akan tercapai. Jadi, metode merupakan salah satu komponen 
dalam proses belajar mengajar yang menentukan keberhasilan pembelajaran. Mengingat peran metode yang demikian penting, maka dalam memilih metode seharusnya memberikan kesempatan bagi siswa untuk berkembang secara kreatif. Di samping itu, dengan penggunaan metode diharapkan dapat menghindari situasi pembelajaran yang verbalistis. Dengan kata lain, situasi kondusif dalam pembelajaran harus diwujudkan agar dapat membangkitkan motivasi, minat, atau gairah belajar di kalangan siswa.

Dari pengamatan awal yang dilakukan mengindikasikan bahwa pembelajaran bahasa-sastra menemui kendala disebabkan oleh metode yang diterapkan guru tidak cocok untuk siswa, dan ditunjang pula alat bantu yang kurang memadai. Di pihak lain, pengajar bahasa-sastra kurang memahami teori bahasa-sastra, teori pembelajaran, peran pembelajaran, peran pengajar, dan peran bahan ajar, serta tujuan pembelajaran bahasa-sastra.

Selain beberapa hal yang dikemukakan di atas, pemilihan metode juga seyogyanya memperhatikan pendekatan. Dalam hal ini dapat dijelaskan bahwa pendekatan merupakan cara pandang yang senantiasa mewarnai dalam pembelajaran bahasa-sastra khususnya. Hendaknya diketahui bahwa metode pada dasarnya merupakan penjabaran dari pendekatan. Karena itu, metode yang dipakai seyogiyanya sejalan dengan yang diisyaratkan pendekatan. Justru itu, sebelum menentukan metode paling tidak memahami secara mendalam pendekatan pembelajaran yang akan dijadikan sebagai rujukan.

Dalam perkembangan pembelajaran bahasa-sastra Indonesia, setidaknya dikenal pendekatan struktural dan pendekatan komunikatif. Pendekatan struktural lebih menekankan pada struktur atau bentuk-bentuk bahasa, sedangkan pendekatan komunikatif menitikberatkan pada pemakaian bahasa sebagai sarana komunikasi. Dengan kata lain, pendekatan struktural mengajarkan tentang bahasa, sedangkan pendekatan komunikatif mengajarkan bahasa. Kedua pendekatan tersebut tentu saja memiliki kelemahan dan kelebihan masing-masing. Pendekatan struktural menjadikan pembelajar menghapal kaidah-kaidah bahasa, tetapi tidak terampil mengunakan bahasa dalam berbagai situasi. Sementara pendekatan 
komunikatif menjadikan para pembelajar mampu menggunakan bahasa, dalam berbagai situasi tetapi agak lemah dalam penguasaan kaidah kebahasaan.

Terkait dengan paparan di atas, sudah menjadi kewajiban bagi para guru agar memahami konsep dan operasional pendekatan komunikatif. Sebab, tanpa adanya pemahaman yang mendalam terhadap pendekatan itu maka tujuan pembelajaran bahasa dan sastra yang diisyaratkan dalam kurikulum dewasa ini sulit tercapai. Meskipun demikian, perlu disadari juga bahwa menerapkan pendekatan komunikatif dalam pembelajaran bahasa dan sastra bukan berarti benar-benar menghilangkan pendekatan struktural. Dengan perkataan, porsi penggunaan pendekatan struktural diminimalkan, sedangkan penggunaan pendekatan komunikatif lebih dioptimalkan.

Secara historis pendekatan struktural lahir karena dilatarbelakangi linguistik struktural yang pernah Berjaya di Amerika. Linguistik struktural ekstrim yang ditokohi oleh Bloomfield (1930-an) menyatakan bahwa yang merupakan objek analisis yang paling sentral dalam analisis bahasa adalah struktur, sedangkan makna dikesampingkan. Alasannya adalah karena strukturlah yang bersifat konkrit, sedangkan makna dianggap bersifat abstrak.

Menurut Pringgawidagda (2002), pendekatan komunikatif sangat tepat dipilih karena beberapa pertimbangan berikut.

1) Pembelajar mempunyai kesempatan untuk mengembangkan kompetensi komunikatif nya

2) Pendekatan komunikatif berorientasi pada pembelajar untuk aktif, kreatif, dan produktif, sementara pengajar mengkondisikan situasi belajar agar pembelajar aktif berpendapat, kreatif menghadirkan ide, dan produktif dalam tindak ajaran.

3) Pendekatan komunikatif mementingkan konteks. Dalam hal ini, pengajar dapat menciptakan konteks yang sesungguhnya ditiru dan dihadirkan di depan kelas.

4) Pelaksanaan pendekatan komunikatif senantiasa melibatkan aspek linguistik dan nonlinguistik (aspek sosial). 
5) Kesalahan berbahasa dianggap wajar sebagai isyarat bahwa terjadi proses pembelajaran di dalam diri pembelajar.

Tujuan pembelajaran dengan pendekatan komunikatif menunjukkan terjadi pergeseran dari tujuan pembelajaran sebelumnya yang lebih didominasi pada kaidah kebahasaan dan kesastraan. Siswa menguasai kaidah tetapi tidak mampu menggunakan bahasa secara praktis. Demikian pula pada aspek pembelajaran sastra, pembelajaran sastra yang bermakna dan apresiatif tidak tampak. Akibatnya adalah siswa tidak memiliki kemampuan berbahasa dan bersastra secara memuaskan. Oleh sebab itu, dalam kaitannya dengan prosedur pemilihan metode yang diketengahkan di atas sudah selayaknya mempertimbangkan pelaksanaan pendekatan komunikatif dalam pembelajaran bahasa-sastra Indonesia.

\section{PEMBAHASAN}

\section{Kultur}

Kultur (budaya) merupakan cara hidup yang berkembang dan dimiliki bersama oleh suatu kelompok yang diwariskan dari generasi ke generasi. Budaya terbentuk dari berbagai unsur termasuk di dalamnya sistem kepercayaan, politik, adat-istiadat, bahasa dan sebagainya (lihat Mahmud dan Suntana, 2012). Bahasa merupakan salah satu unsur budaya yang tidak terpisahkan dengan manusia. Manusia akan menyesuaikan diri ketika berkomunikasi dengan orang lain di luar kelompoknya. Hal ini membuktikan bahwa budaya itu dipelajari.

Terkait dengan hal di atas, ratna (2010:418) mengemukakan bahwa pendekatan apa pun yang dilakukan dapat dipastikan bahwa bahasalah yang dianalisis sebab merupakan satu-satunya alat atau medium yang membentuk karya sastra. Dalam karya sastra, bahasa merupakan medium. Dalam karya sastra bahasa dipelajari melalui retorika dan stilistika. Lebih lanjut, Ratna (2010:418) memaparkan bahwa membaca karya sastra berarti harus memecahkan dua gejala sekaligus, yaitu bahasa dan sastra itu sendiri. Hal ini jelas berbeda dengan seni lukis, misalnya penikmat tidak harus terlibat dengan masalah-masalah yang berkaitan material yang lain. Masalah yang terpenting yang perlu diperhatikan 
dalam kaitannya dengan bahasa sastra adalah banyak sifat-sifat yang dimiliki, misalnya ambiguitas, konotatif, metaforis, simbolis dan sebagainya.

Dengan demikian, bahasa tidak dapat dilepaskan dari konteks sosial budaya masyarakat penuturnya (Hymes, 1972 dan 1989) karena selain merupakan fenomena sosial, bahasa juga merupakan fenomena budaya. Sebagai fenomena sosial, bahasa merupakan suatu bentuk perilaku sosial yang digunakan sebagai sarana komunikasi. Oleh karena itu, berbagai faktor sosial yang berlaku dalam komunikasi, seperti hubungan peran di antara peserta komunikasi, tempat komunikasi berlangsung, tujuan komunikasi, situasi komunikasi, status sosial, pendidikan, usia, dan jenis kelamin peserta komunikasi, juga berpengaruh dalam penggunaan bahasa. Sementara itu, sebagai fenomena budaya, bahasa selain merupakan salah satu unsur budaya, juga merupakan sarana untuk mengekspresikan nilai-nilai budaya masyarakat penuturnya. Atas dasar itu, pemahaman terhadap unsur-unsur budaya suatu masyarakat-di samping terhadap berbagai unsur sosial yang telah disebutkan di atas-merupakan hal yang sangat penting dalam mempelajari suatu bahasa.

Perlu disadari bahwa dalam suatu tatanan masyarakat tidak bisa dihindari bahwa setiap individu dipastikan terikat oleh konvensi atau nilai sosial dari nilai budaya masyarakatnya termasuk dalam pemakaian bahasa. Nilai dalam konteks ini bertalian dengan kaidah dalam pemakaian bahasa (kaidah sosial).

Terkait dengan kebudayaan, guru membantu pembelajar dalam proses transformasi nilai-nilai kehidupan. Adapun nilai-nilai yang ditransformasikan mencakup nilai-nilai religi, nilai-nilai kebudayaan, nilai-nilai sains dan teknologi, nilai-nilai seni, dan nilai-nilai keterampilan. Nilai-nilai yang ditransformasikan tersebut dimaksudkan untuk mempertahankan, melestarikan, dan mengembangkan kebudayaan yang lebih baik dan maju.

Dalam hubungan ini, salah satu cara untuk memperkenalkan nilai-nilai luhur bangsa adalah dengan memperkenalkan budaya lokal kepada anak didik. Nilainilai budaya lokal ini adalah jiwa dari kebudayaan lokal dan menjadi dasar dari segenap wujud kebudayaan di daerahnya. Memperkenalkan cerita rakyat dalam bentuk mendongeng sebelum tidur misalnya merupakan budaya bangsa kita 
dahulu, yang pada masa kini sudah mulai meluntur seiring berkembangnya zaman. Cerita merupakan salah satu sarana penting untuk mempertahankan eksistensi diri. Cerita tidak hanya digunakan untuk memahami dunia dan mengekspresikan gagasan, ide-ide, dan nilai-nilai, melainkan juga sebagai sarana penting untuk memahamkan dunia kepada orang lain, menyimpan, mewariskan gagasan dan nilai-nilai tersebut dari generasi ke generasi berikutnya.

Bertolak pada paparan di atas, dapat dipastikan bahwa dalam pemilihan metode pembelajaran bahasa-sastra aspek kultur seyogiyanya diperhatikan guru. Selain pembelajaran bahasa, aspek kultur juga menarik dijadikan bahan pertimbangan dalam pembelajaran sastra. Dengan memperhatikan kultur, maka pembelajaran sastra akan lebih bermakna.

Namun satu hal yang pasti, faktor penggunaan metode pembelajaran sastra di sekolah erat sekali hubungannya dengan penumbuhan minat belajar pada siswa. Hasil pengamatan dan wawancara dengan rekan-rekan guru menunjukkan bahwa selama ini pembelajaran sastra cenderung bersifat teoritis. Hal ini berhubungan dengan berbagai faktor, termasuk faktor kemampuan guru dan fasilitas belajar. Kurikulum sebenarnya tidak menuntut pemberlakuan metode tertentu melainkan menghendaki untuk menggunakan berbagai metode secara bervariasi dalam penyajian materi pembelajaran sehingga tujuan pembelajaran tercapai. Karena itu, orientasi pada pengajaran mengenai konsep teori sastra tampaknya sudah saatnya supaya porsinya dikurangi. Yang lebih dipentingkan dewasa ini adalah mengupayakan pengakraban siswa dengan karya sastra sehingga mereka menemukan keasyikan personal dalam membaca, mengkritik, dan mengkreasi teks sastra. Metode respon-analisis, strata norma, dan pendekatan-pendekatan lain secara bervariasi sudah saatnya digunakan dalam pengkajian teks sastra di kelas. Untuk itu, guru perlu membaca buku dan media cetak lain yang menjelaskan konsep dasar dan teknik penerapan metode.

\section{SIMPULAN}

Berdasarkan uraian yang telah dipaparkan sebelumnya, maka dapat disimpulkan bahwa dalam memilih dan menerapkan metode pembelajaran 
bahasa-sastra seyogyanya memperhatikan dua aspek, yaitu prosedur dan kultur (budaya). Prosedur berkaitan dengan pemilihan metode pembelajaran dengan menyesuaikan tingkat perkembangan intelektual dan sosial, mempertimbangkan fasilitas yang tersedia di sekolah, dan menyesuaikan sifat dan tujuan pembelajaran. Kemudian, bertalian dengan kultur menghendaki agar dalam pembelajaran bahasa-sastra senantiasa mempertimbangkan aspek kultur (budaya).

\section{Daftar Pustaka}

Hymes, Dell. 1972. Model of the Interaction of Language and Social Life" dalam Gumperz, John and Hymes, Dell (ed). Directions in Sociolinguistics. New York: Holt, Rinehart, and Winston, hlm. 59-65.

Hymes, Dell. 1989. Foundations in Sociolinguistics: An Etnographic Approach. Philadelphia: The University of Pennsylvania Inc.

Krashen, S.D. 1988. Second Language Acquisition and Second Language Learning. New York : Prentice Hall International Ltd.

Mahmud, H dan Suntana, 2012. Antropologi Pendidikan. Bandung: Pustaka Setia.

Priggawidagda, Suwarna. 2002. Strategi Penguasaan Berbahasa. Yogyakarta : Adicita.

Ratna, Nyoman Kutha. 2010. Sastra dan Cultural Studies (Representasi Fiksi dan Fakta.). Yogyakarta: Pustaka Pelajar.

Richards, J.C. dan Rodgers, Th.S. 2002. Methodology in Language Teaching. Cambridge : Cambridge university press.

Richards, J.C. dan Rodgers, Th.S. 2007. Approach and Method In Language Teaching. Cambridge : Cambridge university press.

Sitirohaniah.blogspot.com diakses 25 Februari 2016. 